\title{
Cosegregation of schizophrenia with Becker muscular dystrophy: susceptibility locus for schizophrenia at Xp21 or an effect of the dystrophin gene in the brain?
}

\author{
Mayana Zatz, Homero Vallada, Marcio S Melo, Maria Rita Passos-Bueno,
} Antonio H G Vieira, Mariz Vainzof, Michael Gill, Valentim Gentil

\begin{abstract}
A family is reported in which four of five adult patients with Becker muscular dystrophy (BMD) also have schizophrenia or related spectrum disorders. Although the estimated lod scores are not sufficient to conclude the existence of linkage between BMD and schizophrenia, it is suggested that there may be an association between these two disorders. Two alternative hypotheses are proposed to explain such an association: (1) the existence of a susceptibility locus for schizophrenia and spectrum disorders on the short arm of the $X$ chromosome at Xp21; (2) that these psychiatric disorders may result from an abnormality in the expression of the dystrophin gene in the brain.

(f Med Genet 1993;30:131-4)
\end{abstract}

A genetic component for schizophrenia is widely accepted, ${ }^{1}$ but its mode of inheritance remains unclear. Linkage studies of psychiatric conditions with polymorphic genetic markers have provided contradictory results to date. Autosomal dominant inheritance with reduced penetrance has been suggested as a possible mode of inheritance for schizophrenia. ${ }^{23}$ Evidence for a susceptibility locus on chromosome 5 in the region q13-15 in Icelandic and English pedigrees ${ }^{4}$ has been reported, but was not supported by studies of other pedigrees. ${ }^{5-11}$ Genetic heterogeneity may explain such disparate findings, but recent reanalysis with new polymorphic markers in that region suggest that it was a false positive result. ${ }^{12}$

The possible association of schizophrenia with other genetic disorders has been discussed previously, ${ }^{13}$ but little is known about the occurrence of psychiatric disorders associated with the $\mathrm{X}$ linked recessive conditions Becker and Duchenne muscular dystrophy (BMD and DMD). Both are disorders characterised by a progressive muscular degeneration and weakness. They are caused by the absence (DMD), or by abnormalities in quantity or quality (BMD), of the muscle protein dystrophin, encoded by a gene located at Xp21. ${ }^{14}$ $\mathrm{DMD}$ is a more severe condition, causing death in the second or, more rarely, in the third decade, whereas most patients with BMD can survive to middle age.

Up to $50 \%$ of DMD patients have some degree of mental retardation, from severe handicap to borderline, ${ }^{15}$ and a reduction of verbal IQ is occasionally found in some cases of BMD. ${ }^{16-18}$ Here, we report a family in which several patients who have BMD also have schizophrenia and schizophrenia spectrum disorder (SSD).

\section{Subjects and methods}

The family (figure) was ascertained through a male with Becker muscular dystrophy who had a schizophrenia-like illness. Relatives were

M R Passos-Bueno

$M$ Vainzof

LIM 23, Laboratório de Investigação

Médica,

Departamento de

Psiquiatria,

Faculdade de

Medicina,

Universidade de São

Paulo, Brazil.

M S Melo

A H G Vieira

V Gentil

Genetics Section,

Institute of

Psychiatry, De

Crespigny Park,

London SE5 8AF.

$\mathrm{H}$ Vallada

M Gill

Correspondence to

Dr Vallada.

Received 1 May 1992.

Revised version accepted

8 July 1992.

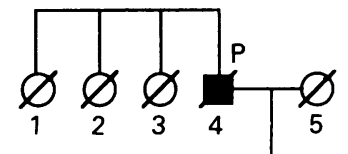

II

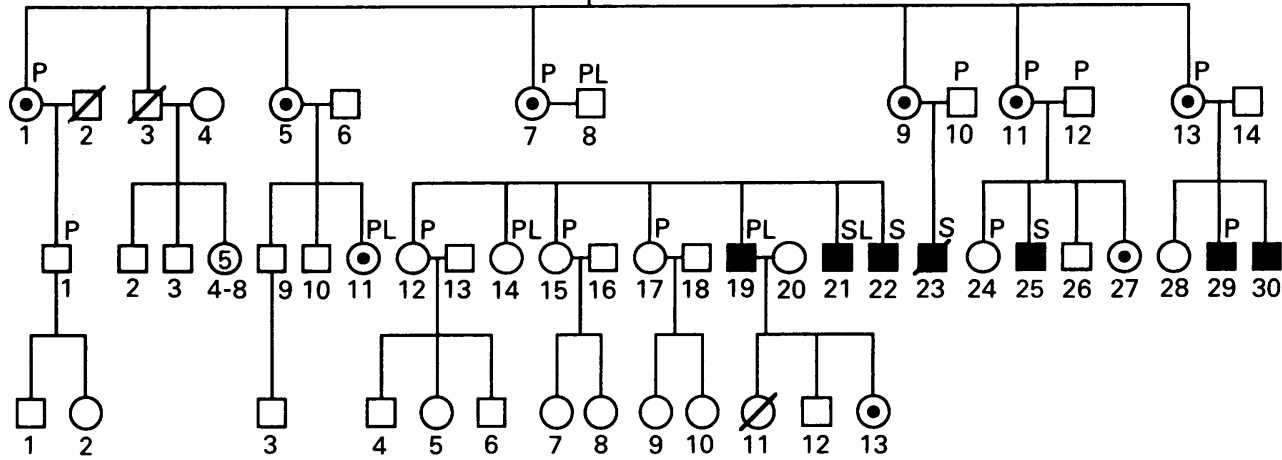

Pedigree showing those members affected with Becker muscular dystrophy ( $)$ ), Becker carriers ( $\odot$ ), schizophrenia and schizophrenia spectrum disorders $(S)$, other psychiatric disorders $(P)$, and leprosy $(L)$. 
traced and clinical and psychiatric examinations performed. The diagnosis of BMD was based on X linked inheritance, disease progression, grossly raised serum creatine kinase (CK) and pyruvate kinase (PK) activities, DNA studies, muscle histology, and dystrophin assessment (immunohistochemistry and western blotting). Since serum $\mathrm{CK}$ and $\mathrm{PK}$ are already raised in preclinical stages of $\mathrm{BMD},{ }^{19}$ these enzymes were assessed in all males at risk for BMD. The methods for serum enzyme determinations, DNA, and dystrophin analysis have been described previously. ${ }^{20-22}$

All psychiatric evaluations were performed during direct interviews with family members using the Schedule for Affective Disorders and Schizophrenia - Life-time version (SADSL $)^{23}$ supplemented by the Structured Interview for DSM-III Personality (SIDP) ${ }^{24}$ when necessary. Only subjects older than 20 years were psychiatrically assessed, with the exception of two young BMD boys evaluated through a structured clinical interview by an experienced child psychiatrist. The diagnosis of subjects already dead was made using the Family Informant Schedule and Criteria (FISC), ${ }^{25}$ and by the criteria proposed by Kendler $e t a l^{26}$ for the retrospective evaluation of possible SSD. All the psychiatric diagnoses were made according to the Research Diagnostic Criteria (RDC). ${ }^{27}$

\section{Results}

The pedigree is depicted in the figure. The majority of members currently live in Brazil, but their progenitors came from Italy on the paternal side and Portugal on the maternal side. The proband (III-21), first ascertained in 1975 at the age of 23, was diagnosed as having BMD and schizophrenia. His grandfather, $I \cdot 4$, had BMD with a very mild clinical progression. He was confined to a wheelchair at the age of 64 and died at the age of 75 of pulmonary oedema. He was a wine producer and a heavy drinker, with a probable diagnosis of alcoholism. He had no other mental or psychiatric disorder. He had one unaffected son (II.3) and six BMD carrier daughters, who between them had a total of eight daughters and 11 sons, seven affected with BMD. In addition, four family members (II 8 , III 14 , III $\cdot 19$, and III $\cdot 21$ ) had leprosy. The diagnosis of BMD could be excluded in other at risk males from generation III and IV on the basis of normal serum CK and PK activities.

DNA analysis in Becker patients showed an 'in frame' deletion ${ }^{28}$ in the region encompassed by exons 45 to 49 , and the presence of an RFLP of exon 51 detected with probe cf56a and restriction enzyme Pst I. ${ }^{29}$ Chromosome analysis showed no abnormality. Among four females from generation III who agreed to collaborate, III 11 and III. 27 were identified as BMD carriers and III $\cdot 12$ and III $\cdot 28$ as noncarriers, based on the presence (III.11 and III.27) or absence (III.12 and III.28) of the RFLP of exon 51 detected in affected patients. Dystrophin western blot analysis showed a protein of reduced molecular weight $(390 \mathrm{kDa}$ upper band) compatible with the DNA deletion. Immunohistochemical analysis showed a pattern typical of BMD.

Psychiatric diagnoses in the five BMD patients who reached adulthood and other members of the family are listed in table 1 . Two boys (III.29 aged 10, and III.30 aged 4) are below the age risk for schizophrenia, but patient III.29 has an attention deficit and hyperactivity disorder. With the exception of a single episode of major depression in subject III $\cdot 1$, the unaffected males in generation III are all psychiatrically normal.

Among other family members, only one BMD carrier (III 11 ) has a paranoid personality which could be included in a broad concept of schizophrenia spectrum disorder. ${ }^{2630}$ However, this is a complex case with other psychiatric diagnoses (Briquet's disease and obsessive-compulsive disorder) and bitemporal epilepsy, which itself is associated with a higher prevalence of psychiatric disorders. ${ }^{31}$

\section{LINKAGE ANALYSIS}

Two point analysis between the BMD gene and schizophrenia spectrum disorder (SSD) was performed using the computer program LINKAGE ${ }^{32}$ and considering different penetrance values $(\mathrm{K})$ for the assumed SSD genotype (table 2). The two young BMD patients, III. 29 and III $\cdot 30$, were not taken into account. The maximum lod score $(1.49)$ was obtained at $\theta=0$ and $K=0 \cdot 7$. If III.29 is considered as affected the maximum lod score would increase to 1.85 at $\theta=0$ and $K=0.7$.

\section{Discussion}

The transmission of schizophrenia spectrum disorder (SSD) in this family is compatible with an X linked recessive pattern of inheritance. The estimated lod scores are not sufficient to prove the existence of linkage between BMD and schizophrenia. However, the observation that of five adult male BMD patients in the pedigree four have schizophrenia or SSD, while six unaffected males have no psychiatric condition, warrants further examination.

$\mathrm{X}$ linked inheritance for psychiatric disorders has been proposed, in particular, a predisposing locus for manic-depression at Xq28. The suggestion that there might be a locus predisposing to schizophrenia on the $\mathrm{X}$ chromosome is based on the following. (1) There is a body of opinion which states that psychotic illness is a continuum from manicdepression through schizoaffective psychosis to schizophrenia with increasing severity of defect state..$^{33}$ (2) Schizophrenia-like psychoses are seen more frequently than would be expected by chance among subjects with sex chromosome aberrations. ${ }^{34}$ (3) Schizophrenialike symptoms have been reported in association with Alport syndrome (hereditary nephritis) ${ }^{35}$ and fragile $X .{ }^{36}$ (4) The finding that there is an excess of same sex over opposite sex pairs in sibs both affected with the disorder. This has led to the pseudoautosomal locus hypothesis for the transmission of psychoses. ${ }^{37}$ This 
Table 1 Psychiatric and non-psychiatric diagnoses for members of the pedigree.

\begin{tabular}{|c|c|c|}
\hline $\begin{array}{l}\text { Family } \\
\text { members }\end{array}$ & Psychiatric diagnoses & Non-psychiatric diagnoses \\
\hline I. 4 & Alcoholism & BMD, very mild progression \\
\hline II $\cdot 1$ & $\begin{array}{l}\text { Recurrent major depression }+ \\
\text { Alzheimer's disease }\end{array}$ & BMD carrier \\
\hline II 5 & & BMD carrier \\
\hline II $\cdot 7$ & Major depression (SE) & BMD carrier \\
\hline II $\cdot 8$ & $\begin{array}{l}\text { Recurrent major depression }+ \\
\text { obsessive-compulsive disorder }\end{array}$ & Leprosy \\
\hline II.9 & & BMD carrier \\
\hline II $\cdot 10$ & Alcoholism & \\
\hline II 11 & Major depression (SE) & BMD carrier \\
\hline II $\cdot 12$ & Alcoholism & \\
\hline II $\cdot 13$ & Major depression (SE) & BMD carrier \\
\hline III $\cdot 1$ & Major depression (SE) & \\
\hline III-11 & $\begin{array}{l}\text { Paranoid personality }+ \text { bitemporal } \\
\text { epilepsy }+ \text { Briquet's disease }+ \\
\text { obsessive-compulsive disorder }\end{array}$ & BMD carrier \\
\hline III 12 & Major depression (SE) & BMD non-carrier \\
\hline III. 14 & Major depression (SE) & Leprosy \\
\hline III 15 & General anxiety disorder & \\
\hline III 17 & Major depression (SE) & \\
\hline III 19 & Major depression $(\mathrm{SE})+$ panic disorder & BMD, mild progression \\
\hline III $\cdot 21$ & Chronic schizophrenia, residual type & $\mathrm{BMD}$, mild progression + leprosy \\
\hline III $\cdot 22$ & Schizotypal personality & $\mathrm{BMD}$, moderate progression \\
\hline III $\cdot 23$ & Schizotypal personality & $\mathrm{BMD}$, severe progression, died aged 17 \\
\hline III $\cdot 24$ & Major depression (SE) & \\
\hline III $\cdot 25$ & Chronic schizophrenia, residual type & BMD, moderate progression \\
\hline III $\cdot 27$ & & BMD carrier \\
\hline III $\cdot 28$ & & BMD non-carrier \\
\hline III. 29 & Attention deficit + hyperactivity disorders & $\mathrm{BMD}$, age 10 \\
\hline III 30 & & $\mathrm{BMD}$, age 4 \\
\hline
\end{tabular}

$\mathrm{SE}=$ single episode
Thus, the high genetic loading might allow the segregation of a predisposing mutation at or near the BMD gene. A mixed mode of inheritance has already been postulated for major affective disorders, ${ }^{40}$ with a major gene producing its effects against a polygenic background.

(2) In this family schizophrenia and related disorders are caused by the effect of an abnormal dystrophin gene in the brain. This may be more common than reported, as it would rarely be identified in the severe forms of DMD since most patients die before the risk period. In fact, such a diagnosis has recently been established by us in the rare case of a DMD patient (with an 'out of frame' deletion of exons 47 to 52 ) who survived to 23 years old (unpublished data). The association of schizophrenia and DMD has also been suggested by other investigators. $^{41}$ In a recent study of 35 BMD patients, ${ }^{4243}$ two had a diagnosis of schizophrenia and one of attention deficit disorder. These patients, as well as the ones from the present family, all have 'in frame' deletions in the dystrophin gene. Although the samples are small, these proportions suggest a higher prevalence of schizophrenia as compared with the $1 \%$ lifetime risk in the general population. ${ }^{44}$

A known characteristic of schizophrenia is decreased reproduction by affected subjects. ${ }^{45}$ Interestingly, this was also observed by us for $\mathrm{BMD}$ in a recent study in which we analysed the reproductive fitness in males affected by autosomal recessive limb-girdle muscular dystrophy (LGMD) as compared with $\mathrm{X}$ linked BMD. ${ }^{4647}$ While in LGMD the fitness was almost normal $(f=0.98)$, in $B M D$ it was greatly reduced $(f=0 \cdot 12)$. Since the physical disability is similar in the two conditions this would not account for the observed differences in reproductive performance. One possibility is that the reduced fitness in BMD could be because of psychological problems in relating to the opposite sex, similar to those observed in schizophrenia.

An isoform of dystrophin, the DMD/BMD product, has been found in the mouse brain, ${ }^{4849}$ and its relation to intellectual function is currently under investigation. ${ }^{1850} \mathrm{Re}$ sults from such studies may provide important data for supporting our second hypothesis.

In conclusion, the apparent cosegregation in this family between Becker muscular dystrophy and schizophrenia, if true, could either be the result of a gene contributing to the mental disorder, linked to the BMD/DMD locus, or alternatively a mutation in the dystrophin gene resulting in a direct effect on the brain.

This work was supported by FAPESP, CNPq, ABDIM, and LIM-23. We thank Professor Robin Murray for encouragement and important suggestions; Dr Francisco Assumpção for child psychiatric evaluation; Drs Mark Lathrop and Joseph Terwilliger for advice on lod score analysis; Dr Debora Rappaport, Mrs Marta Canovas, Mrs Martha Alessandra, $\mathrm{Mr}$ Reinaldo Takata, and Dr Simone Campiotto for their collaboration; and special thanks to 
Dr Osvaldo Frota-Pessoa for suggestions and invaluable support.

1 Gottesman II, Shields J. Schizophrenia, the epigenetic puzzle. London: Cambridge University Press, 1982

2 Slater E. The monogenic theory of schizophrenia. Acta Genet 1958;8:50-6.

3 Heston LL. The genetics of schizophrenia and schizoid disease. Science 1970;167:249-56.

4 Sherrington R, Brynjolfsson J, Pertursson $\mathrm{H}$, et al. Localization of a susceptibility locus for schizophrenia on chromosome 5. Nature 1988:336:164-7.

5 Kennedy JI, Giuffra LA, Moises HW, et al. Evidence against linkage of schizophrenia to markers on chromosome 5 in a northern Swedish pedigree. Nature 1988;336:167-70.

6 Detera-Wadleigh SD, Goldin LR, Sherrington R, et al. Exclusion of linkage to 5q11-13 families with schizophrenia and other psychiatric disorders. Nature 1989;340:391-3.

7 St Clair D, Blackwood D, Muir W, et al. No linkage of chromosome 5q11-q13 markers to schizophrenia in Scottish families. Nature 1989;339:305-7.

8 Gilliam TC, Freimer NB, Kaufmann CA, et al. Deletion mapping of DNA markers to region of chromosome 5 that cosegregates with schizophrenia. Genomics 1989;5:940-4.

9 McGuffin P, Sargeant M, Hett G, et al. Exclusion of a schizophrenia susceptibility gene from the chromosome 5q11-q13 region: new data and a reanalysis of previous reports. Am ₹ Hum Genet 1990;47:524-35.

10 Ashauer HN, Treiber GA, Isenberg KE, et al. No evidence for linkage between chromosome 5 markers and schizophrenia. Hum Hered 1990;40:109-15.

11 Hallmayer J, Maier W, Ackenheil M, et al. Evidence agains linkage of schizophrenia to chromosome 5q11-q13 markers in systematically ascertained families. Biol Psychiatry 1992;31:83-94.

12 Gurling H. 82nd Meeting of the American Psychopathological Association, New York, March 1992.

13 Propping P. Genetic disorders presenting as 'schizophrenia'. Karl Bonhoeffer's early view of the psychoses in phrenia . Karl Bonhoeffer's early view of the psychoses in

14 Kunkel LM, Hejtmancik JF, Caskey CT, et al. Analysis of deletions in DNA in patients with Becker and Duchenne deletions in DNA in patients with Becker and
muscular dystrophy. Nature 1986;322:73-7.

15 Dubowitz V. Muscle disorders in childhood. London Saunders, 1978

16 Bortolini ER, Zatz M. Investigation on genetic heterogeneity in Duchenne muscular dystrophy. $A m \mathcal{J} \mathrm{Med}$ Genet 1986;24:111-7.

17 Emery AEH. Duchenne muscular dystrophy. Oxford: Oxford Medical Publications, 1987.

18 Rappaport D, Passos-Bueno MR, Brandao L, et al. Apparent association of mental retardation and specific patterns of deletions screened with probes cf56a and $\operatorname{cf} 23 \mathrm{a}$ in Duchenne muscular dystrophy. Am $f$ Med Genet 1991;39:437-41.

19 Zatz M, Rappaport D, Vainzof M, et al. Serum creatinekinase (CK) and pyruvate-kinase (PK) activities in kinase (CK) and pyruvate-kinase (PK) activities in
Duchenne (DMD) as compared with Becker (BMD) muchenne (DMD) as compared with Becker

20 Zatz M, Shapiro LJ, Campion DS, et al. Serum pyruvatekinase (PK) and creatine-phosphokinase (CK) in progressive muscular dystrophies. F Neurol Sci 1978;36:349-62.

21 Passos-Bueno MR, Rappaport D, Love D, et al. Screening of deletions in the dystrophin gene with the cDNA probes cf $23 a$, cf56a, and cf1 15. ₹ Med Genet 1990;27:145-50.

22 Vainzof M, Pavanello RCM, Pavanello I, et al. Dystrophin immunostaining in muscles from patients with different types of muscular dystrophy: a Brazilian study. 7 Neurol Sci 1990;98:221-33.

23 Spitzer RL, Endicott J. Schedule for affective disorders and schizophrenia. Lifetime version. 3rd ed. New York: New schizophrenia. Lifetime version. 3rd ed.
York State Psychiatric Institute, 1979.

24 Pfohl B, Stangl D, Zimmerman BA. Structured interview for DSM-III personality - SIDP. 2nd ed. Department of Psychiatry, University of Iowa, 1983.
25 Mannuzza S, Fyer AJ, Endicott J, Klein DF. Family informant schedule and criteria. New York State Psychiatinformant schedule
ric Institute, 1985.

26 Kendler KS, Masterson CC, Ungaro R, Davies KL. A family history study of schizophrenia related personality disorders. Am f Psychiatry 1984;141:424-7.

27 Spitzer RL, Endicott J, Robins E. Research diagnostic criteria for a selected group of functional disorders. 3rd ed. New York State Psychiatric Institute, 1985.

28 Koening M, Beggs AH, Moyer M, et al. The molecular basis for Duchenne versus Becker muscular dystrophy: correlation of severity with type of deletion. Am $\mathcal{J}$ Hum Genet 1989;45:498-506.

29 Forrest SM, Cross GS, Speer A, et al. Preferential deletion of exons in Duchenne and Becker muscular dystrophies. Nature 1987;329:638-40.

30 Kendler KS. Heritability of schizophrenia. Am $\mathcal{F}$ Psychiatry 1983;140:131.

31 Hermann BP, Whitman S. Epilepsy - behavioral and personality correlates: a review, methodological critique and sonality correlates: a review, methodological critiqu
conceptual model. Psychol Bull 1984;95:451-97.

32 Lathrop GM, Lalouel JM, Julier C, Ott J. Strategies for multilocus linkage analysis in human. Proc Natl Acad Sci USA 1984;81:3443-6.

33 Crow TJ. Nature of the genetic contribution to psychotic illness - a continuum viewpoint. Acta Psychiatr Scand 1990;81:401-8.

34 DeLisi LE, Crow TJ. Evidence for sex chromosome locus for schizophrenia. Schizophr Bull 1989;15:431-40.

35 Shields GW, Pataki C, DeLisi LE. A family with Alport syndrome and psychosis. Schizophr Res 1990;3:235-9.

36 Reiss AL, Hagerman RJ, Vinogradov S, et al. Psychiatric disability in female carriers of the fragile $\mathrm{X}$ chromosome. Arch Gen Psychiatry 1988;45:25-30

37 Crow TJ DeL isi LE, Johnstone EC. Concordance by sex in sibling pairs with schizophrenia is paternally inherited. Evidence for a pseudoautosomal locus. Br $\mathcal{f}$ Psychiatry 1989;155:92-7.

38 Curtis $D$, Gurling $H$. Unsound methodology in investigating pseudoautosomal locus in schizophrenia. Br f Psychiatry 1990;156:415-6.

39 Fisher EM, Aliato T, Luoh SW, et al. Human sex chromosome specific repeats within a region of pseudoautosomal/ Yq homology. Genomics 1990;7:625-8.

$40 \mathrm{McGuffin} \mathrm{P}$. Major genes for major affective disorder? $\mathrm{Br} \mathcal{F}$ Psychiatry 1988;153:591-6.

41 DeLisi LE, Crow TJ. Sex chromosome anomalies and schizophrenia. Psychiatr Genet 1991;1:103.

42 Abe $\mathrm{M}$, Arai M, Machara $\mathrm{K}$, et al. A case of Becker muscular dystrophy with schizophrenia symptoms. Brain Nerve 1990;42:1061-6.

43 Beggs AH, Hoffman EP, Snyder JR, et al. Exploring the molecular basis for variability among patients with Becker muscular dystrophy: dystrophin gene and protein studies. Am ₹ Hum Genet 1991;49:54-67.

44 Lander ES. Splitting schizophrenia. Nature 1988;336:105-

45 Saugstad L. Social class, marriage, and fertility in schizophrenia. Schizophr Bull 1989;15:9-43.

46 Passos-Bueno MR, Vainzof M, Pavanello RCM, et al. Limb-girdle syndrome: a genetic study of 22 large Brazilian families: comparison with $\mathrm{X}$-linked Duchenne and lian families: comparison with X-linked Duchenn

47 Passos-Bueno MR, Zatz M. Reproductive fitness and frequency of new mutations in Becker muscular dystrophy: implication for genetic risk estimates $\mathcal{F}$ Med Genet 1991;28:286-8.

48 Chelly J, Hamard G, Koulakoff A, et al. Dystrophin gene transcribed from different promoters in neuronal and glial cells. Nature 1990;344:64-5.

49 Livod HGW, Byers TJ, Watkins SC, Kunkel LM. Localization of dystrophin to postsynaptic regions of central nervous system cortical neurons. Nature 1990;348:725-7.

50 Rappaport D, Passos-Bueno MR, Takata IR, et al. A deletion including the brain promoter of the Duchenne muscular dystrophy gene is not associated with mental muscular dystrophy gene is not associated 